\title{
PERILAKU CROSS-LAMINATED TIMBER (CLT) SEBAGAI MATERIAL UTAMA BANGUNAN TINGKAT MENENGAH TAHAN GEMPA DI INDONESIA
}

\author{
Ika Rahmawati Suyanto* \\ Peneliti / Sekolah Vokasi/Departemen Teknik Sipil / Universitas Gadjah Mada \\ *Korespondensi: ika.rahmawati.s@ mail.ugm.ac.id
}

\begin{abstract}
Cross-laminated timber (CLT) is made up of multilayered timber stacked perpendicularly, which improved the dimensional stability and allowing CLT to has high bearing capacity in its two direction. Despite all the advantages, CLT has not yet gain much attention in Indonesian, especially the utilization in mid-rise building construction. In order to have a better understanding about CLT as main structural element, the behaviour of mid-rise building made of CLT was assessed by running a 3D model of 5-story building by combining building code in Indonesia with CLT parameter from previous researcher as well as recommended adjustment from previous researchers. The research shows that CLT building statisy the allowable parameter for mid-rise building in Indonesia.
\end{abstract}

Keywords: Cross-laminated timber, seismic resistant building, wooden shearwall

\section{PENDAHULUAN}

Dewasa ini, kebutuhan akan tempat tinggal kian meningkat sedangkan lahan yang tersedia semakin sempit. Maka dalam suatu daerah padat penduduk, sering kali dijumpai dibangun hunian bertingkat seperti apartemen guna mengoptimalkan penggunaan lahan terbatas agar dapat menampung lebih banyak orang. Di sisi lain, tingginya tingkat aktivitas konstruksi menimbulkan sebuah kekhawatiran akan limbah yang dihasilkan baik selama proses konstruksi maupun limbah dari gedung lama yang dibongkar dan atau dihancurkan [1]. Isu ini erat kaitannya terhadap konsep pembangunan berkelanjutan. Menanggapi isu tersebut, kayu kembali dipertimbangkan sebagai bahan bangunan [2].

Pada dasarnya, sejak dahulu kayu telah digunakan sebagai bahan bangunan. Selain ringan, kayu memiliki keunggulan berupa harga yang murah, mudah didapatkan, dan mudah dikerjakan dalam banyak desain. Namun, kayu merupakan bahan yang cenderung mudah terbakar dan mudah lapuk terutama di daerah beriklim tropis. Akibatnya, banyak bangunan khususnya di daerah padat penduduk yang menggunakan beton yang dinilai lebih tahan lama.
Cross-laminated timber (CLT) adalah salah satu jenis kayu laminasi dikembangkan untuk mengeliminasi kelemahan yang sebelumnya ada pada material kayu [3]. Dalam proses fabrikasi, CLT ditekan sedemikian rupa sehingga lebih padat hingga pori-pori pada kayu menjadi sangat kecil. Hal ini membuat CLT tidak mudah terbakar [4].

Pada dasarnya di Indonesia, terutama pada bangunan tingkat menengah, kayu laminasi umumnya dipakai sebagai komponen non-struktural seperti dinding partisi maupun fasad. Pada penelitian ini, kegunaan kayu laminasi CLT dipelajari secara lebih lanjut sebagai komponen struktural yang mampu menahan gaya lateral sesuai dengan standar bangunan tahan gempa di Indonesia.

Tujuan dari penelitian ini adalah mengamati perilaku dari bangunan tingkat menengah yang tersusun dari panel-panel CLT terhadap standar standar bangunan yang berlaku di Indonesia dengan pemodelan 3D menggunakan SAP2000.

Sebagai batasan masalah, pemodelan ini berfokus pada perilaku struktur CLT di atas tanah. Sedangkan untuk perilaku, dimensi, dan kapasitas fondasi tidak tercakup dalam studi ini. 


\section{TINJAUAN PUSTAKA}

\subsection{Definisi Cross-Laminated Timber}

Cross-laminated timber (CLT) adalah kayu laminasi yang tersusun dari minimum 3 lapis plywood dengan arah serat kayu yang berbeda antar lapisannya [5]. Arah serat yang berbeda membuat CLT lebih optimal untuk digunakan sebagai komponen struktural berbentuk panel, tidak seperti glulam yang umum digunakan sebagai komponen kolom dan balok.

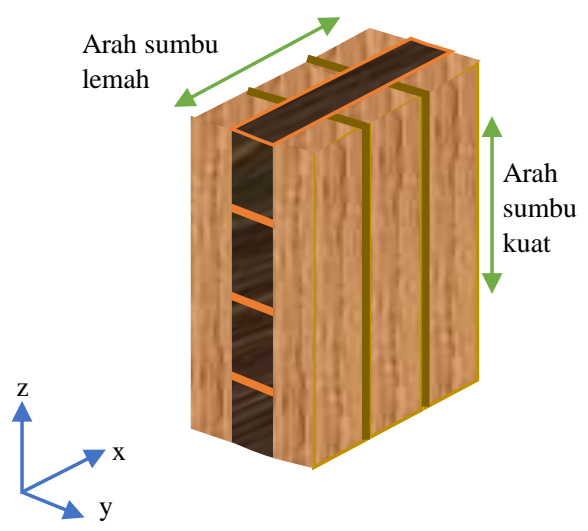

\section{Gambar 1. Penampang CLT}

Panel CLT memiliki sumbu lemah dan sumbu kuat sehingga penentuan arah pemasangan panel menjadi penting baik dalam pemodelan dan pelaksaan dilapangan.

\subsection{Penyesuaian Parameter Untuk Struktur Cross-Laminated Timber}

Dalam standar bangunan tahan gempa Indonesia, gaya geser akibat gempa yang mengenai struktur harus didesain dengan koefisien modifikasi respon yang sesuai, $R$, faktor amplifikasi defleksi, $C_{d}$, dan faktor kuat lebih sistem, $\Omega_{0}$. Berdasarkan SNI 1726:2012 [6], digunakan nilai $C_{d}=2$ dan $\Omega_{0}=2,5$ untuk sistem dinding rangka ringan dengan panel geser. Sementara itu diambil nilai $R=2$ untuk CLT yang mengacu pada Pei, et al [7].

Pada panel elemen dengan bukaan seperti jendela, Dujic [8] menyatakan bahwa nilai kekakuan geser dan kekuatan geser sangat bergantung pada rasio luas bukaan terhadap luas panel. Pada model ini, dinding CLT yang terjepit oleh kusen pintu diasumsikan sebagai dinding non-struktural sehingga tidak ditampilkan pada pemodelan 3D (lihat Gambar 2). Sedangkan untuk dinding dengan jendela, kapasitas dari panel CLT didekati dengan faktor pengali sebesar 0,5 .

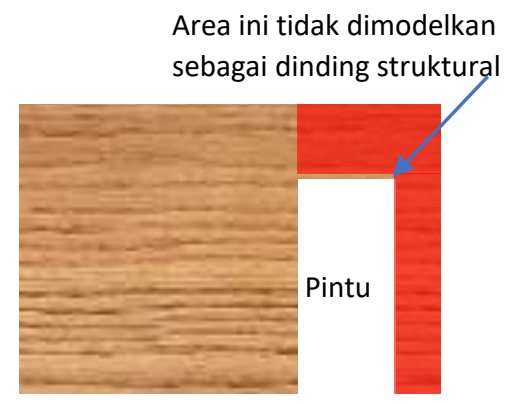

Gambar 2. CLT Dengan Pintu

Di samping itu, dalam memodelkan material perlu adanya input berupa nilai perbandingan antara penyempitan atau kontraksi dengan regangan longitudinal yang dikenal sebagai rasio poisson. Maldonado dan Chui [9] mengusulkan nilai rasio poisson untuk CLT sebesar $v=0,3$.

\section{METODE PENELITIAN \\ 3.1 Bagan Alur Penelitian}

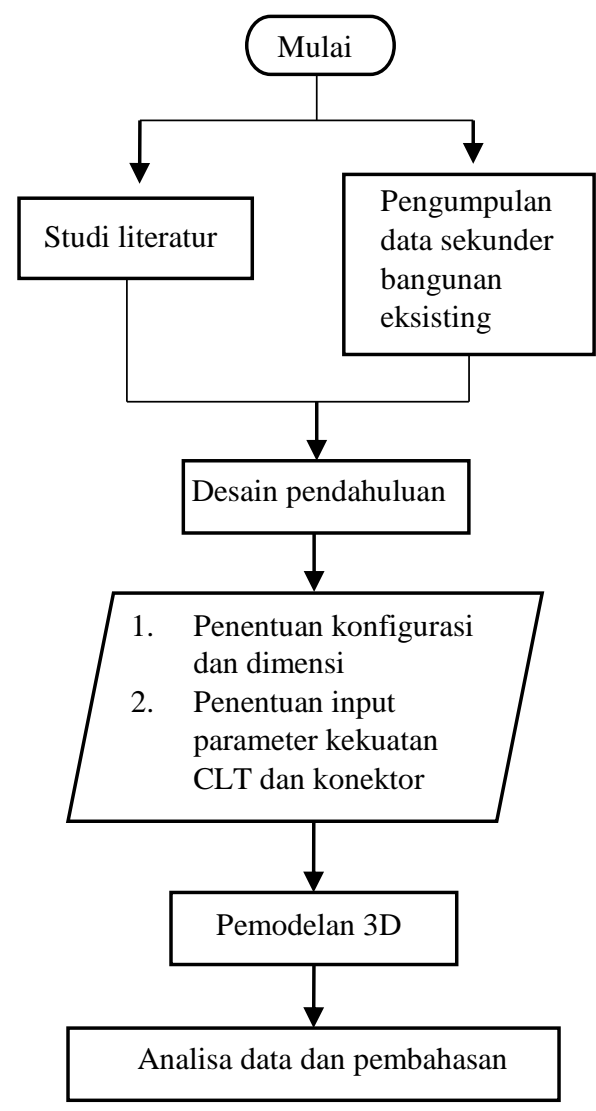

Gambar 3. Diagram Alur Penelitian 
Penelitian ini dilakukan dalam beberapa tahapan sehingga pemodelan dapat menggambarkan perilaku yang lebih mendekati keadaan yang sesungguhnya. Adapun tahapan penelitian dapat dilihat pada Gambar 3.

\subsection{Menentukan Properti Kekuatan Cross- Laminated Timber}

CLT memiliki kekuatan yang berbeda pada tiap sumbunya sesuai dengan komposisi lapisan kayu beserta arah seratnya atau lebih dikenal dengan istilah anisotropik. Kekuatan CLT yang digunakan dalam penelitian ini didasarkan pada jenis CLT yang umum berada di pasaran dunia yaitu CLT Grade E1 yang terbuat dari Black Spruce Pine. Besarnya parameter kapasitas CLT Grade E1 dapat dilihat pada Tabel 1 dan Tabel 2.

Tabel 1. Kekuatan CLT Grade E1 di Sumbu Kuat

\begin{tabular}{|c|c|c|c|c|c|c|}
\hline $\mathbf{f}_{\mathbf{b}, \mathbf{0}}$ & $\mathbf{E}_{0}$ & $\mathbf{f}_{\mathbf{t}, \mathbf{0}}$ & $\mathbf{f}_{\mathrm{c}, 0}$ & $\mathbf{f}_{\mathrm{v}, \mathbf{0}}$ & $\mathbf{f}_{\mathrm{s}, 0}$ & $\mathbf{G}_{0}$ \\
\hline Mpa & Mpa & Mpa & Mpa & Mpa & Mpa & Mpa \\
\hline 28,3 & 11722 & 19,9 & 23,6 & 2,9 & 0,97 & 732,6 \\
\hline
\end{tabular}

Tabel 2. Kekuatan CLT Grade E1 di Sumbu Lemah

\begin{tabular}{c|c|c|c|c|c|c}
\hline $\begin{array}{c}\mathbf{f}_{\mathbf{b}, \mathbf{0}} \\
\text { Mpa }\end{array}$ & $\begin{array}{c}\mathbf{E}_{\mathbf{0}} \\
\mathrm{Mpa}\end{array}$ & $\begin{array}{c}\mathbf{f}_{\mathbf{t}, \mathbf{0}} \\
\mathrm{Mpa}\end{array}$ & $\begin{array}{c}\mathbf{f}_{\mathbf{c}, \mathbf{0}} \\
\mathrm{Mpa}\end{array}$ & $\begin{array}{c}\mathbf{f}_{\mathbf{v}, \mathbf{0}} \\
\mathrm{Mpa}\end{array}$ & $\begin{array}{c}\mathbf{f}_{\mathbf{s}, \mathbf{0}} \\
\mathrm{Mpa}\end{array}$ & $\begin{array}{c}\mathbf{G}_{\mathbf{0}} \\
\mathrm{Mpa}\end{array}$ \\
\hline 7,2 & 8274 & 3,6 & 8,5 & 2,9 & 0,96 & 517,1 \\
\hline
\end{tabular}

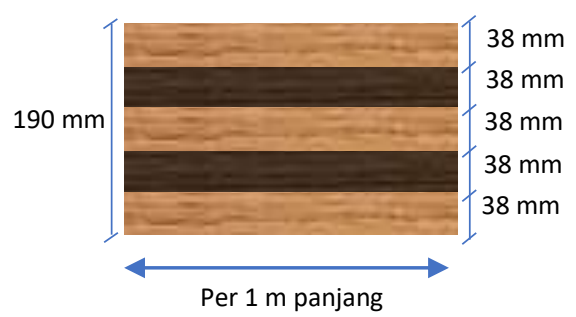

Gambar 3. Panel Dinding dan Lantai CLT

Modulus elastisitas efektif, $E I_{\text {eff, }}$, suatu panel CLT dapat dihitung dengan Persamaan 1. Sedangkan untuk kekakuan geser efektif, $G A_{\text {eff }}$, dapat ditentukan sebagai berikut:

$$
\begin{aligned}
& \left(E \Gamma_{\text {eff }}=\sum_{i=1}^{n} E_{i} b_{i} \frac{h_{i}^{2}}{12}+\sum_{i=1}^{n} E_{i} A_{i} z_{i}^{2}\right. \\
& G A_{\text {eff }}=\frac{a^{2}}{\left(\frac{h_{i}}{2 G_{i} b}\right)+\left(\sum_{i=2}^{n-1} \frac{h_{i}}{G_{i} b_{i}}\right)+\left(\frac{h_{n}}{2 G_{n} b}\right)}
\end{aligned}
$$

dengan:

$E_{i}=$ modulus elastisitas $b$ = lebar lapisan

$A_{i}=$ luas penampang panel

$z_{i}=$ jarak dari titik pusat penampang panel

$h=$ tebal lapisan

$\mathrm{a}=$ total tebal seluruh lapisan

Nilai modulus elastisitas dan kekakuan geser penampang berbeda pada arah sumbu kuatnya dan arah sumbu lemah. Maka, penentuan arah pemasangan panel akan mempengaruhi perilaku struktur.

Kapasitas dalam menahan gaya tegak lurus bidang (out-of-plane) ditentukan oleh modulus elastisitas tekuk arah $\mathrm{x}, E_{r x}$, dan arah $\mathrm{y}, E_{r y}$ serta ditentukan oleh modulus geser bidang zx, $G_{z x}$, dan bidang yz, $G_{y z}$. Okabe et. al [10] mengulkan nilai $E_{r x}, E_{r x}, G z x$, dan $G z y$ melalui persamaan berikut:

$E_{r x}=\frac{(E I)_{e f f x}}{I_{f u l l} x} \quad E_{r y}=\frac{(E I)_{e f f y}}{I_{f u l l y}}$

$G_{z x}=\frac{(G A)_{\text {effy }}}{I_{f u l l} y} \quad G_{y z}=\frac{(E I)_{\text {eff } x}}{I_{\text {full } x}}$

dengan $I_{\text {full } x}$ adalah inersia utuh penampang arah $x$ dan $I_{\text {full } y}$ adalah inersia utuh penampang arah y.

Dalam penelitian Yasumura, et al [11] mengusulkan bahwa kapasitas dalam menahan gaya sebidang (in-plane) ditentukan oleh modulus elastisitas arah $\mathrm{x}, E_{x}$, dan arah y, $E_{y}$ serta ditentukan oleh modulus geser bidang xy, $G_{x y}$. Nilai $E_{x}, E_{x}$, dan $G_{x y}$ didapatkan sebagai berikut:

$E_{x}=\frac{\sum_{i} E_{x i}}{n_{p}} \quad E_{y}=\frac{\sum_{i} E_{y, i}}{n_{p}}$

$G_{x y}=\frac{E_{y}}{e_{1}}$

dengan:

$E_{x, i}=$ modulus elastisitas pada tiap lapisan yang memiliki serat searah arah $\mathrm{x}$

$E_{y, i}=$ modulus elastisitas pada tiap lapisan yang memiliki serat searah arah y

$n_{p}=$ jumlah lapisan

$e_{1}=16$ (untuk CLT produk Amerika)

\subsection{Pemodelan Dengan SAP2000}

Penelitian ini menggunakan studi kasus sebuah gedung asrama di Yogyakarta. Gedung 5 lantai dengan panjang, $P=60 \mathrm{~m}$, dan lebar, $L$ $=19,2 \mathrm{~m}$, dirancang menggunakan panel CLT tanpa adanya elemen balok dan kolom 
melainkan dinding dan slab saja seperti yang tampak pada Gambar 4-6. Input pembebanan yang digunakan dalam pemodelan merujuk pada peraturan SNI 1727:2013 [12].

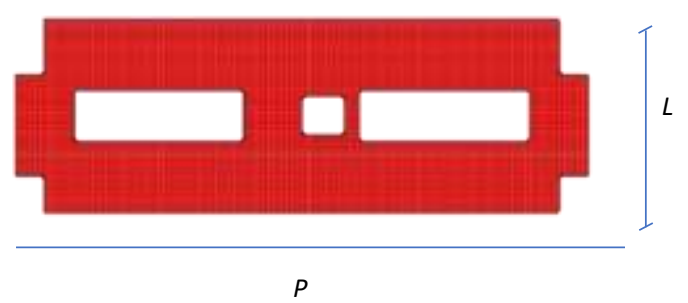

Gambar 4. Tampak atas lantai tipikal (tampak $\mathrm{XY}$ )

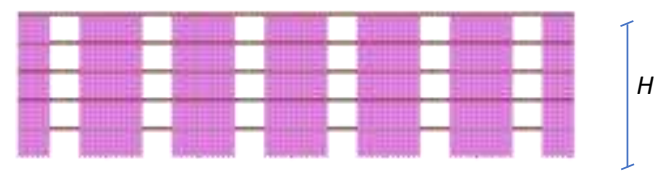

Gambar 5. Tampak depan (tampak XZ) dengan tinggi, $H=14 \mathrm{~m}$

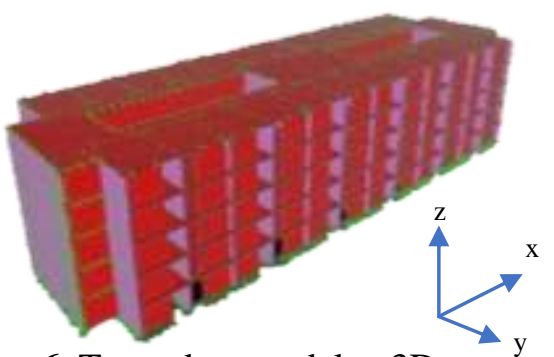

Gambar 6. Tampak pemodelan 3D

Kekuatan panel CLT yang digunakan sebagai input dalam SAP2000 didapatkan dari Persamaan dengan penyesuaian notasi. Nilai modulus elastisitas CLT dan modulus geser pada arah sumbu lokalnya berturut-turut dapat dilihat pada Tabel 3 dan Tabel 4.

Tiap panel CLT dihubungkan dengan baut dan plat penyambung yang terbuat dari baja. Dalam pemodelan menggunakan SAP2000, sambungan ini dimodelkan dengan menggunakan link dengan kekuatan yang mengacu pada Gavric [13] dan disesuaikan dengan sumbu lokal pada SAP2000.

Tabel 3. Nilai Modulus Elastisitas Panel CLT Tanpa Bukaan

\begin{tabular}{c|c|c}
\hline \multicolumn{3}{|c}{ Modulus geser } \\
\hline \multirow{2}{*}{ Notasi } & Input SAP2000 & $\begin{array}{c}\text { Nilai } \\
\text { Mpa }\end{array}$ \\
\hline$E_{r x}$ & $E_{12}$ & 439.556 \\
\hline$E_{r y}$ & $E_{13}$ & 102.670 \\
\hline$\left(E_{x}+E_{y}\right) / 2$ & $E_{23}$ & 77.285 \\
\hline
\end{tabular}

Tabel 4. Nilai Modulus Geser Panel CLT Tanpa Bukaan

\begin{tabular}{c|c|c}
\hline \multicolumn{3}{|c}{ Modulus geser } \\
\hline Notasi & Input SAP2000 & $\begin{array}{c}\text { Nilai } \\
\text { Mpa }\end{array}$ \\
\hline$G_{x y}$ & $G_{12}$ & 439.556 \\
\hline$G_{z x}$ & $G_{13}$ & 102.670 \\
\hline$G_{y z}$ & $G_{23}$ & 77.285 \\
\hline
\end{tabular}

Konektor pada CLT diklasifikasikan ke dalam tiga kategori berdasarkan jenis elemen yang disambung yaitu konektor dinding-lantai, konektor dinding-dinding tegak lurus, dan konektor CLT dan beton yang diasumsikan merupakan lantai kerja di mana struktur CLT akan berdiri. Adapun input kekuatan link dapat dilihat pada Tabel 5-7.

Tabel 5. Notasi dan Input Kekuatan Link Dinding-Lantai

\begin{tabular}{c|c|c}
\hline SAP2000 & Gavric & Nilai \\
\hline Stiffness U1 & $k_{e l .3}$ & $2,98 \mathrm{kN} / \mathrm{mm}$ \\
\hline Stiffness U2 & $k_{\text {el. } 2}$ & $1,10 \mathrm{kN} / \mathrm{mm}$ \\
\hline Stiffness U3 & $k_{\text {el. } 1}$ & Rigid \\
\hline $\begin{array}{c}\text { Damping coefficient } \\
\text { U1 }\end{array}$ & $v_{3}$ & $1,74 \%$ \\
\hline $\begin{array}{c}\text { Damping coefficient } \\
\text { U2 }\end{array}$ & $v_{2}$ & $11,70 \%$ \\
\hline $\begin{array}{c}\text { Damping coefficient } \\
\text { U3 }\end{array}$ & $v_{1}$ & -
\end{tabular}

Tabel 6. Notasi dan Input Kekuatan Link Dinding-dinding Tegak Lurus

\begin{tabular}{c|c|c}
\hline SAP2000 & Gavric & Nilai \\
\hline Stiffness U1 & $k_{\text {el. } 3}$ & $2,90 \mathrm{kN} / \mathrm{mm}$ \\
\hline Stiffness U2 & $k_{\text {el. } 2}$ & $1,49 \mathrm{kN} / \mathrm{mm}$ \\
\hline Stiffness U3 & $k_{\text {el. }}$ & $1,30 \mathrm{kN} / \mathrm{mm}$ \\
\hline $\begin{array}{c}\text { Damping coefficient } \\
\text { U1 }\end{array}$ & $v_{3}$ & $12,66 \%$ \\
\hline $\begin{array}{c}\text { Damping coefficient } \\
\text { U2 }\end{array}$ & $v_{2}$ & $1,15 \%$ \\
\hline $\begin{array}{c}\text { Damping coefficient } \\
\text { U3 }\end{array}$ & $v_{1}$ & $10,41 \%$
\end{tabular}

Tabel 7. Notasi dan Input Kekuatan Link CLT dan Beton

\begin{tabular}{c|c|c}
\hline SAP2000 & Gavric & Nilai \\
\hline Stiffness U1 & $k_{\text {el. } .3}$ & $2,09 \mathrm{kN} / \mathrm{mm}$ \\
\hline Stiffness U2 & $k_{e l .2}$ & $2,53 \mathrm{kN} / \mathrm{mm}$ \\
\hline Stiffness U3 & $k_{\text {el. }}$ & Rigid \\
\hline
\end{tabular}

\subsection{Kontrol Dimensi Penampang CLT yang Menahan Lentur}

Dimensi penampang CLT harus dikontrol terhadap kapasitasnya agar tidak terjadi kegagalan sobek [14]. Tahanan terhadap 
momen lentur dihitung dengan batasan sebagai berikut:

$M_{b} \leq 1,72 S_{e f f}$

$S_{\text {eff }}=\frac{2(E I)_{\text {eff }}}{E_{i} a}$

dengan:

$M_{b}=$ Momen hasil analisa 3D

$S_{\text {eff }}=$ modulus penampang efektif

Sedangkan untuk batas tahanan terhadap geser tegak lurus bidang dapat dihitung menggunakan persamaan berikut:

$V_{\text {plannar }} \leq 1,36\left(\frac{l b}{Q}\right)_{e f f}$

$\left(\frac{b}{Q}\right)_{\text {eff }}=\frac{E I_{\text {eff }}}{\sum_{i=1}^{n / 2} E_{\mathrm{i}} h_{\mathrm{i}} z_{i}}$

dengan $V_{\text {plannar }}$ adalah gaya geser hasil analisa dinamik.

Batas defleksi pada elemen lentur dapat dicari dengan pendekatan sebagai berikut:

$\Delta=\frac{K_{i} w l^{2}}{E I_{\text {app }}}$

$E I_{\text {app }}=\frac{E I_{\text {eff }}}{1+\frac{K_{g} E I_{\text {eff }}}{G A_{\text {eff }} L^{2}}}$

dengan:

$K_{i}=(6 / 5)\left(k_{s} / k_{b}\right)$

$w=$ beban merata

$l$ = panjang elemen

\subsection{Kontrol Dimensi Penampang CLT yang} Menahan Aksial-Lentur

Berdasarkan SNI 7973:2013 [15] Standar bangunan kayu, kapasitas komponen yang menahan aksial-lentur dapat dicari dengan persamaan sebagai berikut:

$$
\begin{gathered}
{\left[\frac{F}{2,16 A_{\text {parallel }}}\right]^{2}+M_{C L T} \leq 1,0} \\
M_{C L T}=\frac{M_{b}+P \times e\left(1+\frac{0.234 F}{P_{C E}}\right)}{1,72 S_{\text {eff }}\left(1-\frac{F}{P_{C E}}\right)} \\
P_{C E} \quad=\frac{0.822 E_{\min }{ }^{\prime}}{\left(l_{e} / d\right)^{2}}
\end{gathered}
$$

dengan:

$F \quad$ = gaya aksial

$P_{c E} \quad=$ beban tekuk kritis

$A_{\text {parallel }}=$ luas lapisan yang arah seratnya paralel dengan beban yang ditanggung e = eksentrisitas gaya aksial diukur tegak lurus terhadap panel

\section{HASIL DAN PEMBAHASAN}

Dari hasil perhitungan terhadap berat struktur, didapati bahwa total berat struktur yang tersusun dari panel-panel CLT lebih ringan, yaitu sebesar hanya $\pm 25 \%$ dari berat struktur beton bertulang. Adapun perbedaan teknis struktur beton bertulang dengan struktur CLT dapat dilihat pada Tabel 8.

Tabel 8. Perbandingan Struktur Dengan Beton Bertulang dan CLT

\begin{tabular}{l|c|c}
\hline \multicolumn{1}{c|}{ Data teknis } & $\begin{array}{c}\text { Beton } \\
\text { bertulang }\end{array}$ & CLT \\
\hline Berat struktur & $51883,4 \mathrm{kN}$ & $10223,59 \mathrm{kN}$ \\
\hline Tebal slab & $\pm 12 \mathrm{~cm}$ & $\pm 19 \mathrm{~cm}$ \\
\hline Tebal dinding & $\pm 20 \mathrm{~cm}$ & $\pm 19 \mathrm{~cm}$ \\
\hline Elemen lentur & Kolom & Slab CLT \\
\hline $\begin{array}{l}\text { Elemen aksial- } \\
\text { lentur }\end{array}$ & Balok & Dinding CLT \\
\hline
\end{tabular}

Berat struktur yang lebih ringan berakibat pada nilai beban lateral yang lebih kecil. Beban lateral yang bekerja pada struktur didistribusikan secara vertikal pada tiap lantai sebagai beban diafragma seperti yang dapat dilihat pada Tabel 9. Sedangkang dari hasil analisis didapatkan kapasitas geser per lantainya sekitar 5345,65 kN.

Tabel 9. Beban Lateral Desain Pada Diafragma Arah x dan Arah y

\begin{tabular}{c|c|c}
\hline Lantai ke- & $\begin{array}{c}\boldsymbol{F}_{\boldsymbol{x}} \\
\mathbf{k N}\end{array}$ & $\begin{array}{c}\boldsymbol{F}_{\boldsymbol{y}} \\
\mathbf{k N}\end{array}$ \\
\hline 5 & 306,69 & 601,39 \\
\hline 4 & 384,89 & 769,78 \\
\hline 3 & 216,50 & 433,00 \\
\hline 2 & 96,22 & 192,44 \\
\hline 1 & 24,06 & 48,11 \\
\hline
\end{tabular}

Ketika struktur dikenai beban lateral, maka struktur akan berdeformasi atau menyimpang searah dengan arah beban. Simpangan terbesar pada ujung bangunan akibat beban lateral arah $\mathrm{x}$ dapat dilihat pada Gambar 7. Sedangkan simpangan terbesar arah y dapat dilihat pada Gambar 8.

Gambar 7 dan Gambar 8 menujukkan bahwa simpangan pada arah y lebih besar dibandingkan arah x. Hal ini dikarenakan lebar gedung hanya sekitar 0,33 dari panjang bangunan sehingga mengindikasikan kekakuan yang lebih kecil. Perbandingan nilai simpangan 
yang telah dikalikan dengan faktor amplifikasi, $C_{d}$, terhadap batas sesuai SNI 1726:2012 [16] dapat dilihat pada Tabel 10.

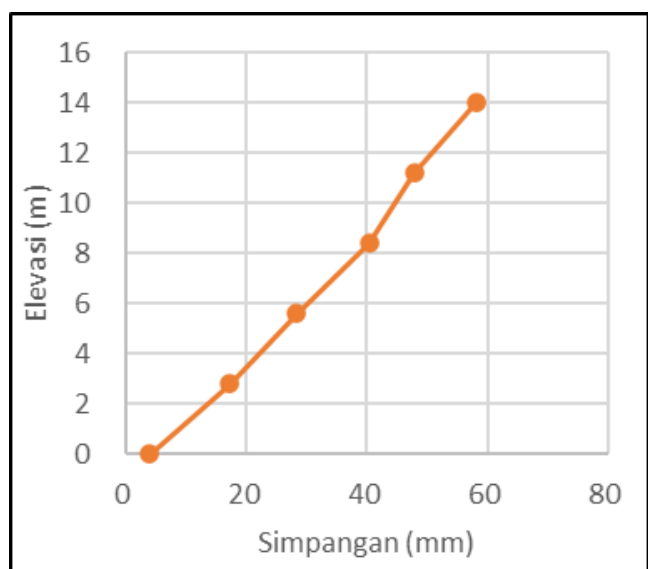

Gambar 7. Grafik Simpangan Pada Arah x

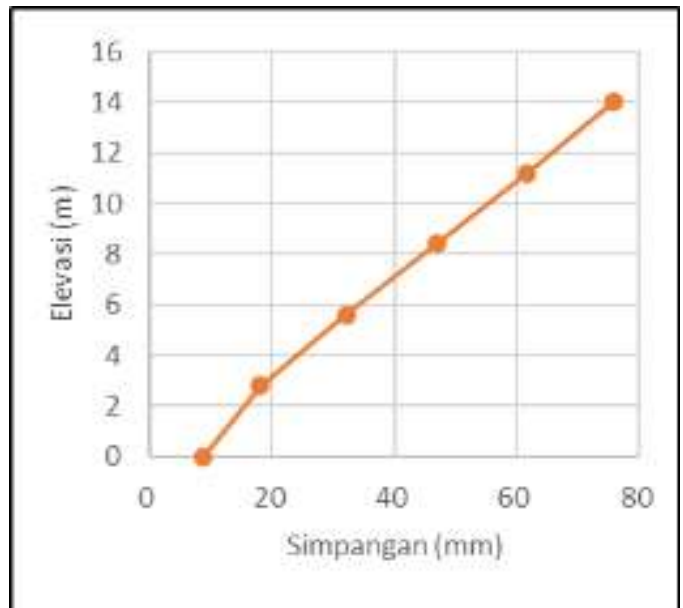

Gambar 8. Grafik Simpangan Pada Arah y

Tabel 10. Simpangan Antar Lantai

\begin{tabular}{c|c|c|c|c}
\hline \multirow{2}{*}{ Lantai } & \multicolumn{2}{|c|}{ Simpangan arah } & \multicolumn{2}{c}{ Simpangan arah } \\
\cline { 2 - 5 } & $\begin{array}{c}\text { Output } \\
\text { rad }\end{array}$ & $\begin{array}{c}\text { Batas } \\
\text { rad }\end{array}$ & $\begin{array}{c}\text { Output } \\
\text { rad }\end{array}$ & $\begin{array}{c}\text { Batas } \\
\text { rad }\end{array}$ \\
\hline 5 & 0,007 & 0,02 & 0,010 & 0,02 \\
\hline 4 & 0,008 & 0,02 & 0,010 & 0,02 \\
\hline 3 & 0,008 & 0,02 & 0,010 & 0,02 \\
\hline 2 & 0,008 & 0,02 & 0,010 & 0,02 \\
\hline 1 & 0,010 & 0,02 & 0,006 & 0,02 \\
\hline *batas simpangan mengacu pada SNI 1726:2012
\end{tabular}

Selain itu, dari hasil analisa 3D didapatkan nilai gaya-gaya yang bekerja. Pada panel dinding CLT tanpa bukaan, interaksi akibat aksial-lentur setelah analisa dengan Persamaan 13 dapat dilihat pada Gambar 9, sedangkan untuk panel dinding CLT dengan bukaan dapat dilihat pada Gambar 10. Dari hasil ini didapatkan bahwa gaya aksial-lentur yang mengenai panel masih lebih kecil dari pada kapasitasnya.

Gambar 9 dan Gambar 10 menunjukkan gaya yang bekerja pada elemen aksial-lentur masih jauh lebih kecil dari pada kapasitas panel, baik pada panel tanpa bukaan atau panel dengan bukaan.

Pada elemen lentur atau pelat, tercatat hasil gaya dalam terbesar adalah 233,84 $\mathrm{kNm} / \mathrm{m}$ sedangkan kapasitas elemen adalah sebesar 292,28 kNm/m. Pada penelitian ini, pelat dimodelkan sebagai rigid sehingga perhitungan terhadap kebutuhan sambungannya tidak termasuk dalam lingkup pembahasan.

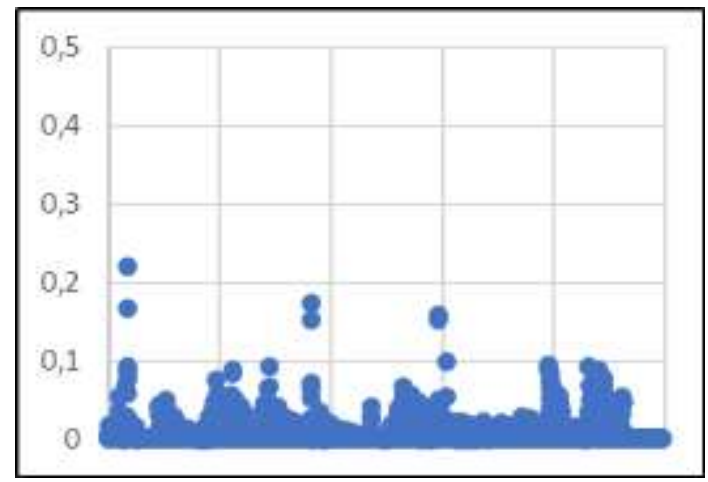

Gambar 9. Grafik Gaya yang Bekerja Pada Elemen Dinding Tanpa Bukaan

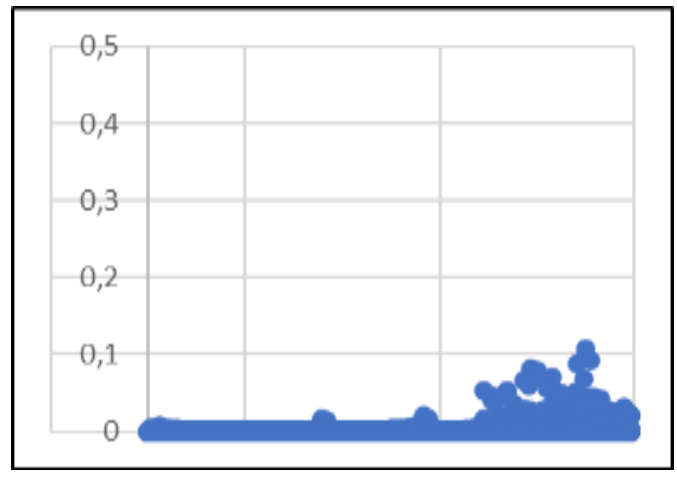

Gambar 10. Grafik Perbandingan Gaya yang

Bekerja dan Kapasitas Elemen Dinding Dengan Bukaan

Selanjutnya, dari hasil analisa gaya-gaya terbesar yang bekerja pada panel, didapatkan pula total kebutuhan konektor di tiap lantai. Hal ini dapat dilihat pada Tabel 11.

Hasil analisa terhadap defleksi terbesar yang terjadi pada panel lantai adalah sebesar $8,6 \mathrm{~mm}$, sedangkan batas defleksi maksimum yang diizinkan adalah $68 \mathrm{~mm}$. Sehingga dapat dikatakan dengan pelat setebal $190 \mathrm{~mm}$ tanpa 
balok mampu menahan beban terbesar bangunan.

Tabel 11. Jumlah Konektor yang Dibutuhkan per Lantai

\begin{tabular}{|c|c|c|}
\hline Lantai ke- & $\begin{array}{c}\text { Gaya geser } \\
\text { kN }\end{array}$ & $\begin{array}{c}\text { Jumlah } \\
\text { konektor } \\
\text { Unit }\end{array}$ \\
\hline 5 & 1572,25 & 96 \\
\hline 4 & 3584,73 & 216 \\
\hline 3 & 4716,75 & 284 \\
\hline 2 & 5219,87 & 316 \\
\hline 1 & 5345,65 & 322 \\
\hline
\end{tabular}

\section{KESIMPULAN}

Hasil analisa dengan pemodelan 3D menggunakan software SAP2000 menunjukkan bahwa bangunan dengan CLT menghasilkan berat struktur yang lebih ringan dibandingkan dengan beton. Di samping itu simpangan antar lantai bangunan dengan CLT akibat beban seismik masih memenuhi batas persyaratan. Hal ini mengindikasikan bahwa CLT dapat digunakan sebagai material utama bangunan kelas menengah yang mampu menahan beban lateral.

\section{DAFTAR PUSTAKA}

[1] Lu, W., Chen X., Peng., \& Shen, L. Benchmarking construction waste management performance using big data. Resources, Conservation, and Recycling Journal, v.105, pp 49-58, 2015.

[2] Lehmann, S. Sustainable Construction for Urban Infill Development using Engineered Massive Wood Panel Systems, Sustainibility Journal, v.4, n.10, pp 2707-2742, 2012.

[3] Brandner, R., et al, Cross laminated timber (CLT): overview and development, European Journal of Wood and Wood Products, v. 74, n. 3, pp 331-351, 2016.
[4] Brandon, D. \& Dagenais, C. Fire Safety Challenges of Tall Wood Buildings Phase 2: Task 5: Experimental Study of Delamination of Cross Laminated Timber in Fire. Fire Protection Research Foundation.

[5] Julien, F. Manufacturing cross-laminated timber (CLT): technological and economic analysis, report to Quebec Wood Export Bureau. Quebec. 2010

[6] SNI 1726:2012 Tata cara perencanaan ketahanan gempa untuk struktur bangunan gedung dan nongedung

[7] Pei, S., Lindt, J. W., \& Popovski, M. Approximate R-Factor for Cross-Laminated Timber Walls in Multisroty Buildings. Journal of Architectural Engineering, ASCE, 19(4), 245255, 2013

[8] Dujic, B. Shear capacity of Cross-Laminated Wooden Walls. Doctoral dissertation: University of Llubjlana, Slovenia, 2006.

[9] Maldonado, S. A., \& Chui, Y. H. Vibrational Performance of Cross-Laminated Timber, 2012

[10] Okabe, M., Yasumura, M. Kobayashi, K., Fujita, K. Prediction of bending stiffness and moment carrying capacity of sugi crosslaminated timber. Journal of Wood Science, 60(1).

[11] Yasumura, M., Kenji, K.,Okabe, M., Miyake, T., \& Matsumoto, K. Full scale tests and numerical analysis of Low-Rise CLT Structures under Lateral Loading. J. Struct. Eng 142 (4), 2015

[11] Sni 1727:2013 Beban minimum untuk perancangan bangunan gedung dan struktur lain

[13] Gagnon, S., Popovski, M., \& Pirvu, C. CLT Handbook Canadian Edition. Quebec: FPInnovations, 2011

[14] Gavric, I. Seismic Behaviour of CrossLaminated Timber for Buildings. Dissertation University of Trieste Italy, 2009.

[15] SNI 7973:2013 Spesifikasi desain untuk konstruksi kayu

[16] SNI 1726:2012 Tata cara perencanaan ketahanan gempa untuk struktur bangunan gedung dan non-gedung 